\section{Loss of Firmness and Changes in Pectic Fractions during Ripening and Overripening of Sweet Cherry}

\author{
B. Fils-Lycaon and M. Buret \\ Institut National de la Recherche Agronomique, Station de Technologies \\ des Produits Végétaux, Domaine Saint Paul, BP 91, 84143 Montfavet \\ cedex, France
}

Additional index words. Prunus avium, texture, softening, neutral sugars

\begin{abstract}
Pectic fractions soluble in water, oxalate, or hydrochloric acid were prepared from an alcohol-insoluble residue of cherry (Prunus avium L., 'Bigarreau Napoléon') tissue. Galacturonic acid and neutral sugar contents were measured during the ripening and overripening of fruit. Fruit firmness was also determined. The changes occurring during fruit development gave prominence to three physiological stages and suggested the progressive degradation of the middle lamella and primary cell wall. The firmness measurement was related to the equilibrium between the relative parts of these pectic fractions.
\end{abstract}

Pectic substances are the major components of the middle lamella and of the primary cell walls of plant tissues. Fruit cell wall composition is very often related to that of the primary cell wall (Knee and Bartley, 1981; Voragen et al., 1983). Many reports have been published on the loss of fruit firmness during ripening. They chiefly concern changes in cell wall components and their enzymatic breakdown (Knee and Bartley, 1981; Huber, 1983). The appearance, during ripening, of pectolytic enzymes, such as pectinesterase (EC 3.1.1.11) and polygalacturonase (EC 3.2.1.15), is often related to softening. Much research has been devoted to studying the involvement of polygalacturonase (Hobson, 1965; Buescher and Tigchelaar, 1975; Poovaiah and Nukaya, 1979; Themmen et al., 1982; Seymour et al., 1987) in tomato fruit softening. However, genetically transformed tomatoes containing anti-sense polygalacturonase still ripen and soften (Smith et al., 1988), and the concept that polygalacturonase is the primary cause for climacteric fruit softening is now altered. However, attempts to find this enzyme activity in strawberry and cherry (two nonclimacteric fruits) have been largely unsuccessful. In strawberry fruit, firmness losses coincide with increased levels of polyuronides (Woodward, 1972; Knee et al., 1977) and a reduction in the viscosity and molecular weight of carbohydrate polymers extracted from cell wall (Huber, 1984). In cherry fruit, knowledge about cell wall breakdown remains meager. Davignon (1961) related that, total pectins increased during ripening, but did not characterize pectic fractions and their neutral associated sugars. This

Received for publication 3 July 1989. We are grateful to M. Souty for galacturonic acid measurement. The cost of publishing this paper was defrayed in part by the payment of page charges. Under postal regulations, this paper therefore must be hereby marked advertisement solely to indicate this fact. characterization was performed by Barbier and Thibault (1982), but was confined to the ripe stage of the fruit.

The aim of our study was to make simultaneous measurements of firmness, pectic fraction and associated neutral sugar changes during ripening and overripening of 'Bigarreau Napoléon' sweet cherry.

'Bigarreau Napoléon' cherries (1200 fruits) were harvested twice a week from the 5th to the 12th week after anthesis. For each of these sampling dates, 80 columns of 15 fruits were made at the laboratory by random sampling. A batch was composed of the 80 fruits of a line; consequently, 15 similar batches (Duprat et al., 1987) were prepared for further studies. Then physico-chemical criteria usually used to characterize changes occurring during fruit ripening were studied. The resulting data were subjected to principal component analysis (PCA). The partitioning on its plane of the different harvests, as defined by the physico-chemical criteria, was progressive with time. The first axis of the PCA plane included $67.25 \%$ of the total variability. It was defined by a first group of criteria characteristic of unripe fruits and by a second group characteristic of ripe fruits. The second axis represented $17.96 \%$ of the total inertia and characterized more precisely the ontogenic stage of the last harvests. This analysis enabled us to test whether the 14 harvests of our experiment differed statistically with increasing physiological fruit age (Fils-Lycaon et al., 1988b).

Firmness measurements were performed on all cherries of one randomly chosen batch. The strength used to squash the fruit to $5 \%$ of its equatorial diameter was measured with a penetrometer designed by Duprat et al. (1986).

Another batch was randomly chosen for pectic fraction analysis. This batch was divided in eight groups of 10 fruits. Fruit flesh of each of these eight groups was frozen in liquid $\mathrm{N}$, homogenized at the same temperature, and stored at $-20 \mathrm{C}$ before pectin preparation. Alcohol-insoluble residue (AIR) was prepared from each of the eight groups using the Barbier and Thibault method (1982). Cherry powder was homogenized for $2 \mathrm{~min}$ in boiling $96 \%$ ethanol $\left(5 \mathrm{ml} \cdot \mathrm{g}^{-1}\right.$ of cherry powder). Sample size was $\approx 20 \mathrm{~g}$. After filtration, the slurry was washed with $96 \%$ ethanol and. the AIR was dried for $24 \mathrm{hr}$ at 40C under vacuum.

Pectic substances were extracted from the AIR as described by Souty et al. (1981). Three fractions were obtained by successive extractions with water (water soluble pectins; WSP), ammonium oxalate (oxalate soluble pectins; OSP) at room temperature, and with boiling hydrochloric acid (HSP) (protopectins).

Galacturonic acid and neutral sugar contents of these fractions were determined using the methods of Thibault (1979) and Tollier and Robin (1979), respectively, both automated by Souty et al. (1980). Results are expressed in milligrams of galacturonic acid and arabinose equivalents per fruit.

Data presented represent the average and SE of 80 and eight measurements for physical and chemical analysis, respectively.

The total pectic content of cherry fruit increased during ripening (Fig. 1). This corroborates the result obtained by Davignon (1961) on the same cultivar. In our assay, physiological ripeness coincided with maximum fruit weight and occurred 8.5 weeks after anthesis (Fils-Lycaon et al., 1988b). At this stage, the total pectin content $(25 \mathrm{mg} /$ fruit) was very close to that observed by Davignon (1961). The total pectin content was constant from 8.5 until 11 weeks after anthesis and decreased thereafter. According to Davignon (1961) this degradation occurs just after the ripe stage.

The changes in the different pectic fractions (Fig. 2) began 6 weeks after anthesis, just before the mature-green stage. These changes continued until 10.5 weeks after anthesis, at which stage the fruit withered drastically. The HSP fraction was the highest during all physiological stages. However, it drastically decreased from $90 \%$ for green fruit to $45 \%$ for overripe fruit. The proportions of

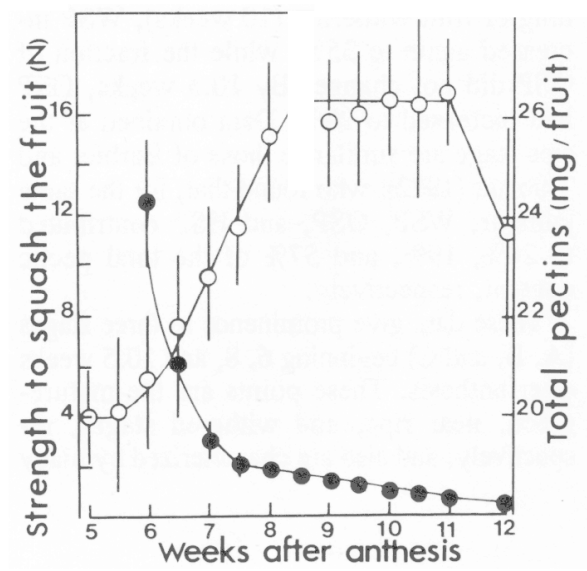

Fig. 1. Changes of total pectin content: O (bars are SES based on eight measurements); and changes of firmness:. (bars are SEs based on 80 measurements) during cherry fruit aging. 


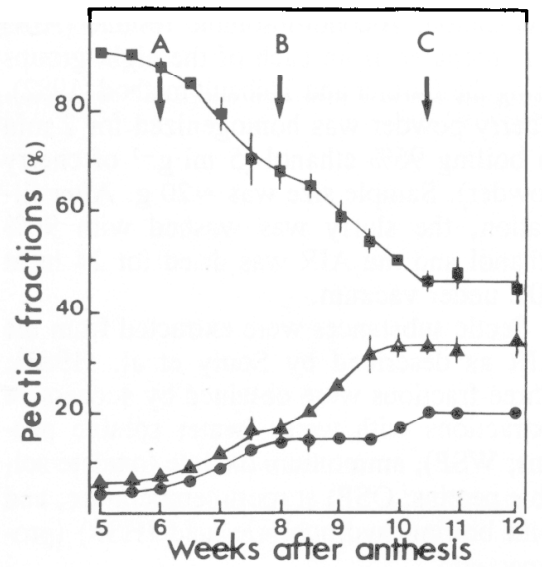

Fig. 2. Changes in the relative fractions of pectic constituents during cherry aging. Pectins soluble in: water (WSP), A; oxalate (OSP), $\bullet$; and hydrochloric acid (HSP), Letters A, B, and $C$ indicate three physiological stages. (Bars are SES based on eight measurements.)

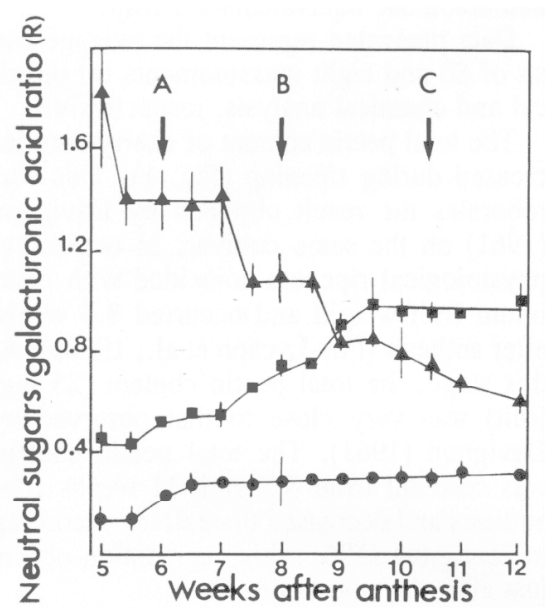

Fig. 3. Changes, during cherry aging, of the neutral sugars/galacturonic acid ratio $(R)$ for the pectic fractions soluble in: water, $\mathbf{A}$; oxalate, ; and hydrochloric acid, $\mathbf{\square}$. Letters A, B, and $\mathrm{C}$ indicate three physiological stages. (Bars are SES based on eight measurements.)

WSP and OSP were similar and increased from $5 \%$ to $15 \%$ between 6.5 and 8 weeks after anthesis. From 8 weeks to the beginning of fruit withering (10 weeks), WSP increased again to $35 \%$, while the fraction of OSP did not change. By 10.5 weeks, OSP had increased to $20 \%$. Data obtained at the ripe stage are similar to those of Barbier and Thibault (1982), who found that, for the same cultivar, WSP, OSP, and HSP contributed to $24 \%, 19 \%$, and $57 \%$ of the total pectic content, respectively.

These data give prominence to three stages (A, B, and C) beginning 6,8, and 10.5 weeks after anthesis.. These points are the maturegreen, near ripe, and withered stages, respectively, and also are characterized by many other biochemical changes (Fils-Lycaon et al., 1988a, 1988b).

The neutral sugars/galacturonic acid ratio (R) for WSP decreased from 1.8 to 0.6 during fruit aging (Fig. 3). $\mathrm{R}$ for OSP increased at the mature-green stage to reach a constant 0.3 . The increase of $\mathrm{R}$ for HSP, from $\approx 0.4$ to 1.0 , peaked near 10 weeks after anthesis, after which changes were absent. The values of the ratios for WSP, OSP, and HSP at the ripe stage are similar to those observed by Barbier and Thibault (1982).

Fruit firmness (Fig. 1) decreased very quickly until 7.5 weeks after anthesis, at which time it no longer changed. This inflection point in firmness was concurrent with the changes in the WSP and OSP fractions.

These data suggest a progressive change in the equilibrium and composition between pectic fractions. The more the HSP decreased, the more neutral sugars were associated with this fraction until the point $\mathrm{C}$. From there on, no changes occurred in the relative parts of the three fractions and in the $\mathrm{R}$ value for HSP.

These observations enable us to make an assumption of a progressive modification or/ and degradation of the middle lamella and primary cell wall during aging. This degradation, leading to fruit softening, would be maximal at the point $\mathrm{C}$. The continued degradation might also explain the severe fruit withering and breakdown occurring in the late physiological stage.

Further studies are needed to characterize the solubilized polyuronides present during fruit aging and cell wall autolysis. Such data will provide an even better understanding of fruit softening.

\section{Literature Cited}

Barbier, M. and J.F. Thibault. 1982. Pectic substances of cherry fruits. Photochemistry $21: 111-$ 115.

Buescher, R.W. and E.C. Tigchelaar. 1975. Pectinesterase, polygalacturonase, $\mathrm{Cx}$-cellulase activities and softening of the rin tomato mutant. HortScience 10:624-625.

Davignon, L. 1961. contribution à l'étude de l'évolution chimique des substances pectiques au tours de la croissance, de la maturation et de la sénescence des fruits. Thése de docteur ingénieur. Université de Paris.

Duprat, F., J. Arakelian, and E. Pietri. 1986. Procédé et appareil d'analyse pénétrométrique notamment pour les fruits et les légumes. French patent no. 8603799

Duprat, F., M. Buret, J. Nicolas, and M. Nicolas. 1987. A methodology of fruit analysis, p. 533538. In: F. E.C.S. (ed.). Proc. 4th European Conf. Food Chem., vol. 108: Rapid analysis in food processing and food control. Loen.

Fils-Lycaon, B., M. Buret, A. Drouet, and C Hartmann. 1988a. Ripening and overripening of a non-climacteric fruit: the sweet cherry Bigarreau Napoléon. 2. Polyribosomal changes. Sci. Alim. 8:459-466.
Fils-Lycaon, B., M. Buret, A. Drouet, C. Hartmann, and F. Duprat. 1988b. Ripening and overripening of cherry fruit: Use of principal component analysis to check fruit picking and sampling method and to select the most discriminant analysis criteria. Sci. Alim. 8:383-396.

Hobson, G.E. 1965. The firmness of tomato fruit in relation to polygalacturonase activity. J. Hort. Sci. 40:66-72.

Huber, D.J. 1983. The role of cell wall hydrolyses in fruit softening. Hort. Rev. 5:169-219.

Huber, D.J. 1984. Strawberry fruit softening: the potential roles of polyuronides and hemicelluloses. J. Food. Sci. 49:1310-1315.

Knee, M. and I.M. Bartley. 1981. Composition and metabolism of cell wall polysaccharides in ripening fruits, p. 133-148. In: J. Friend and M.J.C. Rhodes (eds.). Recent advances in the biochemistry of fruits and vegetables. Academic, New York.

Knee, M., S.A. Sargent, and D.J. Osborne. 1977. Cell wall metabolism in developing strawberry fruits. J. Expt. Bot. 28:377-396.

Poovaiah, B.W. and A. Nukaya. 1979. Polygalacturonase and cellulase enzymes in the normal rutgers and mutant rin tomato fruits and their relationship to the respiratory climacteric. Plant Physiol 64:534-537.

Seymour, G. B., S.E. Harding, A.J. Taylor, G.E. Hobson, and G.A. Tucker. 1987. Polyuronide solubilization during ripening of normal and mutant tomato fruit. Photochemistry 26: 18711875.

Smith, C. J. S., C.F. Watson, J. Ray, C.R. Bird, P.C. Morris, W. Schuch, and D. Grierson. 1988. Antisense RNA inhibition of polygalacturonase gene expression in transgenic tomatoes. Nature (London) 334:724-726.

Souty, M., F. Lapize, and L. Breuils. 1980. Possibilités de dosage simultané sur autoanlyseur de l'acide galacturonique et des oses neutres lors de la détermination des substances pectiques. Ann. Technol Agr. 29:87-96.

Souty, M., J.F. Thibault, G. Navarro-Garcia, J.M. Lopez-Rota, and L. Breuils. 1981. Les substances pectiques de l'abricot (Prunus armeniaca L.) var. Rouge du Roussillon. Caractéristiques globales et étude par chromatographie d'échange d'ions. Sci. Alim. 1:6780.

Themmen, A. P. N., G.A. Tucker, and D. Grierson. 1982. Degradation of isolated tomato cell walls by purified polygalacturonase in vitro. Plant Physiol. 69:122-124.

Thibault, J.F. 1979. Automatisation du dosage des substances pectiques par la méthode au métahydroxydiphényl. Lebensm. Wiss. Technol. 12:247-251.

Tollier, M.J. and J.P. Robin. 1979. Adaptation de la méthode à l'orcinol sulfurique au dosage automatique des glucides neutres totaux: conditions d'adaptation aux extraits d'origine végétale. Ann. Technol. Agr. 28:1-15.

Voragen, A. G. J., J.P.J. Timmers, J.P.H. Linssen, H.A. Schols, and W. Pilnik. 1983. Methods of analysis for cell wall polysaccharides of fruit and vegetables. Z. Lebensm. Unters. Forsch. 177:251-256.

Woodward, J.R. 1972. Physical and chemical changes in developing strawberry fruits. J. Sci. Food. Agr. 23:465-473. 